\title{
PEMANFAATAN ASAP CAIR KAYU PUTIH (Malaleuca cajuputi) SEBAGAI ANTIOKSIDAN DALAM PENGOLAHAN IKAN TUNA ASAP
}

\section{UTILIZATION OF EUCALIPTUS LIQUID SMOKE (Malaleuca cajuputi) ANTIOXIDANTS IN SMOKE TUNA FISH PROCESSING}

\author{
Daniel Ambrosius Nicolas Apituley, Jusuf Leiwakabessy \& Esterlina Elizabeth Elsina Martha \\ Nanlohy
}

FakultasmPerikanan dan Ilmu Kelautan, Universitas Pattimura

Jl. Mr. Chr. Soplanit. Kampus Poka, Ambon. 9723

Alamat korespodensi: Apituley02@yahoo.com

\begin{abstract}
Abstrak: Asap cair mempunyai peluang untuk digunakan secara luas di Maluku karena ketersediaan bahan baku yang melimpah terutama bahan baku yang berasal dari limbah hasil pertanian maupun hasil pengolahan minyak kayu putih. Batang dan ranting kayu putih dapat digunakan sebagai bahan baku dalam pembuatan asap cair. Asap cair yang dibuat melalui pirolisis kayu putih tersebut mengandung komponen senyawa yang dapat berperan sebagai antioksidan yang dapat menghambat maupun mencegah terjadinya proses oksidasi. Penelitian ini bertujuan untuk mengkaji komponen kimia penyusun asap cair yang dapat berperan sebagai antioksidan serta kemampuannya dalam mencegah terjadinya kerusakan oksidatif pada ikan Tuna asap. Hasil analisis dengan GC-MS menunjukkan bahwa fenol dan berbagai derivatnya merupakan komponen yang paling dominan dalam asap cair kayu putih. Hasil uji dpph menunjukkan kemampuan komponen senyawa asap cair kayu putih memiliki potensi sebagai antioksidan yang baik. Kemampuan sebagai antioksidan ditunjukkan oleh asap cair kayu putih dalam menghambat laju peningkatan nilai TBA dan asam lemak bebas ikan Tuna asap selama penyimpanan.
\end{abstract}

Kata kunci: Asap cair kayu putih, antiokasidan, ikan asap

\begin{abstract}
Liquid smoke has a chance to be widely used in Maluku because of abundant availability of raw materials, especially raw materials derived from agricultural waste and the processing of eucalyptus oil. Eucalyptus stems and twigs can be used as raw material in the manufacture of liquid smoke. Liquid smoke is made by pyrolysis of eucalyptus contains components of a compound that can act as an antioxidant that can inhibit or prevent the process of oxidation. This research aims to assess the liquid smoke constituent chemical components that can act as an antioxidant and its ability to prevent oxidative damage to the Tuna smoke. The results of the analysis by GC-MS showed that phenol and various derivatives are the most dominant component in eucalyptus liquid smoke. DPPH test results demonstrate the ability of components of liquid smoke eucalyptus compound has potential as a good antioxidant. Ability as an antioxidant shown by liquid smoke eucalyptus in inhibiting the rate of increase in TBA value and free fatty acids during storage of smoked tuna fish.
\end{abstract}

Keywords: Eucalyptus liquid smoke, antioxidant, smoked fish

\section{PENDAHULUAN}

Pengasapan merupakan salah satu cara pengawetan yang sering digunaan untuk mengatasi masalah kerusakan dan kemunduran mutu ikan. Hal ini disebabkan karena komponen kimiawi dalam asap memiliki kemampuan sebagai antimikroba dan dapat mencegah kerusakan oksidatif pada ikan. Pengasapan umumnya dilakukan dengan metode tradisional. Namun, metode ini sangat sulit dilakukan jika berada di daerah perkotaan. Ada berbagai masalah yang timbul yakni, sulitnya mendapat bahan baku serta gangguan polusi udara. Selain itu, ada beberapa kelemahan pengasapan tradisional antara lain kesulitan dalam mengatur flavor dan konsentrasi konstituen asap yang diinginkan, produk yang dihasilkan tidak seragam karena waktu dan suhu optimal tidak dapat dipertahankan sama, serta kemungkinan terbentuknya senyawa hidrokarbon aromatik polisiklik (benzopyrene) yang belakangan diketahui bersifat karsinogenik. Untuk itulah dilakukan berbagai cara dalam mengatasi masalah tersebut.

Asap cair merupakan salah satu alternatif teknologi dalam upaya perbaikan pengolahan ikan asap. Kelebihan dari teknologi asap cair ini antara lain proses pengasapan dapat dikontrol, produk asapan seragam, cita rasa dan aroma spesifik, lebih aman bagi kesehatan dan lingkungan serta daya awet lebih panjang (Maga, 1987). Disamping itu juga asap cair memiliki potensi sebagai pengawet karena kemampuannya sebagai antimikroba, antioksidan dan antijamur. Salah satu bahan baku yang dapat digunakan dalam produksi asap cair ini adalah batang/ranting kayu putih. Umumnya tumbuhan kayu 
putih lebih banyak dimanfatkan daunnya untuk dijadikan minyak yang disebut minyak atsiri. Manfaat dari kayu putih antara lain sebagai antiseptik dan bakteri, insektisida, decongestant dan expectorant, kosmetik dan analgesik (Wikipedia, 2009). Setelah daunnya diambil, batang/ ranting kayu putih dibiarkan begitu saja dan sering pula digunakan sebagai kayu bakar. Dasar pemikiran dari siklus biologis tanaman kayu putih yang cepat sekali tumbuh dan dengan tekstur yang keras inilah yang dapat dijadikan alternatif dalam memanfaatkan kayu putih sebagai bahan baku pembuatan asap cair. Asap cair mengandung berbagai senyawa yang terbentuk karena terjadinya pirolisis tiga komponen utama yakni selulosa, hemiselulosa dan lignin. Kandungan lignin yang terdapat pada bahan akan menentukan aroma produk asapan, hal ini dikarenakan pada proses pirolisis lignin akan menghasilkan senyawa fenol dan eter fenolik seperti guaiakol (2-metoksi fenol) dan syringol (2,6dimetoksifenol) yang berpengaruh terhadap aroma asap (Girard, 1992). Senyawa-senyawa fenolik ini juga dapat berperan sebagai antioksidan alamiah dari asap cair yang sangat berpengaruh dalam menghambat oksidasi, sehingga daya awet produk dapat dipertahankan. Penelitian ini bertujuan untuk mengkaji komponen kimia penyusun asap cair kayu putih yang dapat berperan sebagai antioksidan serta kemampuannya dalam mencegah terjadinya kerusakan oksidatif pada ikan Tuna asap.

\section{BAHAN DAN METODE Bahan Penelitian}

Bahan yang digunakan dalam penelitian ini yaitu batang dan ranting kayu putih dari desa Suli, ikan Tuna yang diperoleh dari nelayan di desa Tulehu Ambon, garam, larutan TBA 0,2\%, larutan TCA 5\%, diklorometan, $\mathrm{H}_{2} \mathrm{SO} 4, \mathrm{Na}_{2} \mathrm{SO}_{4}$ dan aquades dan bahan lain yang diperlukan yang berada di tempat penelitian. Sedangkan peralatan yang digunakan dalam penelitian ini adalah alat produksi asap cair, botol sampel, erlenmeyer, timbangan analitik, kertas saring, tanur, corong, gelas kimia, gelas ukur, pipet, blender, tabung reaksi, magnetic stirer, oven, spektrofotometri, pisau, talenan, saringan, waskom, dan seperangkat alat GC-MS. Ikan yang digunakan dalam penelitian ini adalah ikan Tuna segar yang dibeli dari nelayan pada saat pendaratannya di Pasar Mardika, Ambon.

\section{Metode Penelitian}

Penelitian ini dilakukan dua tahap, tahap pertama adalah pembuatan asap cair dari ranting kayu putih dan redestilatnya. Asap cair dibuat dengan melakukan pirolisis terhadap ranting kayu putih pada pirolisator dengan suhu $400^{\circ} \mathrm{C}$ seperti yang dilakukan oleh Tranggono dkk., (1996) dan proses redistilasi asap cair dilakukan dengan mengunakan penangas oli dengan suhu antara $100-125^{\circ} \mathrm{C}$. Asap cair dan redestilatnya kemudian dianalisis komposisi kimiawinya yang meliputi kadar fenol (Senter dkk., 1989) kadar karbonil (Lappin dan Clarck, 1951) dan total asam (AOAC, 1990) serta profil komponen penyusunnya dengan menggunakan GC-MS QP2010S SHIMADZU (modifikasi dari Guillen \& Ibargoitia, 1999). Kondisi operasional GC-MS QP2010S saat digunakan adalah sebagai berikut: Suhu oven $75^{\circ} \mathrm{C}$ dipertahankan selama 2 menit, kemudian ditingkatkan menjadi $130^{\circ} \mathrm{C}$ dengan kecepatan peningkatan suhu $8^{\circ} \mathrm{C} /$ menit dan dipertahankan selama 3 menit, ditingkatkan lagi menjadi $290^{\circ} \mathrm{C}$ dengan kecepatan peningkatan suhu $10^{\circ} \mathrm{C} /$ menit yang dipertahankan selama 3 menit dan kemudian ditingkatkan lagi menjadi suhu $300^{\circ} \mathrm{C}$ selama 24 menit. Suhu sumber ion $200^{\circ} \mathrm{C}$. Helium yang digunakan memiliki kemurnian 99,99\%. Tekanan gas diatur 75,0 kPa dan laju aliran gas 0,57 $\mathrm{ml} / \mathrm{menit}$ sedangkan suhu injektor $250^{\circ} \mathrm{C}$. Uji penangkapan radikal bebas DPPH dilakukan dengan metode yang dikemukakan oleh Burda dan Oleszek (2001). Pada tahap dua, redistilat yang dihasilkan dari tahap pertama kemudian diaplikasikan dalam proses pengolahan ikan Tuna asap. Aplikasi asap cair pada pengolahan ikan asap dilakukan sebagai berikut: ikan tuna segar disiangi, dicuci dan dipotong kemudian direndam dalam larutan dengan perlakuan tanpa asap cair (kontrol/A0), redestilat asap cair kayu putih 2,5\% (A1) dan 5\% (A2) selama 4 menit kemudian dipanaskan dalam oven hingga matang. Ikan asap yang dihasilkan kemudian dikemas dalam plastik dan di simpan pada suhu kamar. Parameter yang digunakan untuk melihat kemampuan redistilat asap cair dalam menghambat kerusakan oksidatif lemak ikan Tuna asap adalah dengan mengukur bilangan kadar asam lemak bebas dan TBA seperti yang dikemukakan oleh Raharjo dkk (1992).

\section{HASIL DAN PEMBAHASAN Asap Cair Kayu Putih}

Asap cair yang digunakan dalam penelitian ini terbuat dari batang dan ranting kayu putih (Malaleuca cajuputi) yang diperoleh dari desa Suli. Sebagai bahan baku pembuatan asap cair, batang dan ranting kayu putih terlebih dahulu dianalisa kandungan selulosa, hemiselulosa dan lignin yang hasil analisanya disajikan pada Tabel 1. Hasil Analisis Varian (ANOVA) laju pertumbuhan harian memperlihatkan interaksi antara strain $(\mathrm{S})$ dan berat awal (B), strain (S) dan kedalaman (K), serta berat awal (B) dan kedalaman (K) yang berpengaruh sangat nyata $(\mathrm{P}<0,01)$, tetapi tidak berpengaruh nyata $(\mathrm{P}>0,05)$ oleh interaksi antara strain $(\mathrm{S})$, berat awal (B) dan kedalaman (K) terhadap LPH. Hasil uji lanjut BNJ dirangkum pada Tabel 1.

Hasil analisis menunjukan bahwa kandungan selulosa kayu putih sebesar 24,25\%. Hasil ini lebih rendah dari kandungan selulosa dalam kayu yang berkisar antara 44,5-56\% (Maga, 1987), dan juga penelitian kandungan selulosa pada cangkang kenari yaitu $32,93 \%$ (Leha, 2009). 
Tabel 1. Kandungan Selulosa, Hemiselulosa dan Lignin Kayu Putih

\begin{tabular}{cc}
\hline Parameter & Kadar (\%) \\
\hline Selulosa & 24,25 \\
Hemiselulosa & 15,38 \\
Lignin & 45,25 \\
\hline
\end{tabular}

Rendahnya kandungan selulosa dalam penelitian ini disebabkan karena perbedaan tempat tumbuh tanaman, yang dapat mempengaruhi kandungan selulosa dan kandungan kimia lainnya dari suatu bahan. Besarnya kandungan selulosa suatu bahan dapat menentukan kadar asam, furan dan air dalam asap cair yang dihasilkan (Girrard, 1992). Kandungan hemiselulosa sebesar $15,38 \%$ lebih rendah dari kandungan hemiselulosa pada kayu keras berkisar antara 18,9-25,5\% (Maga, 1987).

Nilai yang dihasilkan ini lebih rendah dari kandungan hemiselulosa tempurung kelapa yaitu $35,55 \%$. Komponen hemiselulosa dalam suatu bahan menentukan kadar furan, furfural, asam karboksilat dan asam asetat dalam asap cair yang dihasilkan. Kandungan lignin kayu putih sebesar 45,25\%, dimana nilai ini lebih besar dari penelitian yang dilakukan oleh Halim (2005) terhadap kandungan lignin cangkang sawit yaitu sebesar $42,85 \%$. Sedangkan penelitian yang dilakukan oleh Tranggono dkk., (1996) terhadap kandungan lignin beberapa jenis kayu berkisar antara 19,35-37,25\%, demikian juga penelitian oleh Darmadji dkk., (1999) dimana kandungan lignin yang diperoleh pada beberapa jenis kayu berkisar antara 17,68-33,34\%.

Hal ini menunjukkan bahwa kandungan lignin yang terdapat pada tanaman kayu putih lebih tinggi dibandingkan dengan cangkang sawit yang telah diteliti. Kandungan lignin dalam suatu bahan akan menentukan aroma pada produk asapan. Hal ini disebabkan karena dalam proses pirolisis lignin akan menghasilkan senyawa fenol dan ester fenolik seperti guaiakol dan siringol yang berpengaruh terhadap aroma asap (Girrard, 1992).

\section{Komponen Penyusun Asap Cair Kayu Putih}

Hasil analisa komponen penyusun dari asap cair kayu putih, dengan menggunakan GC-MS dapat dilihat pada Tabel 2.

Dari hasil analisa GC-MS (Tabel 2) teridentifikasi dapat 27 puncak yang terdiri dari berbagai senyawa, dimana senyawa yang teridentifikasi didominasi oleh fenol dan derivatnya serta beberapa senyawa karbonil dan asam-asam organik lainnya. Sesuai dengan fungsinya sebagai pemberi citarasa (flavor), antioksidan maupun antimikrobia maka senyawa fenolik, karbonil serta asam-asam organik tersebut diharapkan dapat berfungsi sebagai biopreservasi yang mencegah atau menghambat terjadinya kerusakan oksidatif dalam daging ikan Tuna asap.

\section{Aktivitas Antioksidan Asap Cair Kayu Putih}

Asap cair yang telah diredestilasi kemudian diuji kemampuan antioksidannya dengan uji aktivitas penangkapan radikal bebas DPPH (1,1-diphenyl-2picrylhydrazyl) (Burda \& Oleszek (2001); Nenadis \& Tsimidou (2002). Hasil uji menunjukkan bahwa aktivitas asap cair sebagai penangkap radikal bebas meningkat seiring dengan naiknya konsentrasi asap cair seperti yang terlihat pada Gambar 1 .

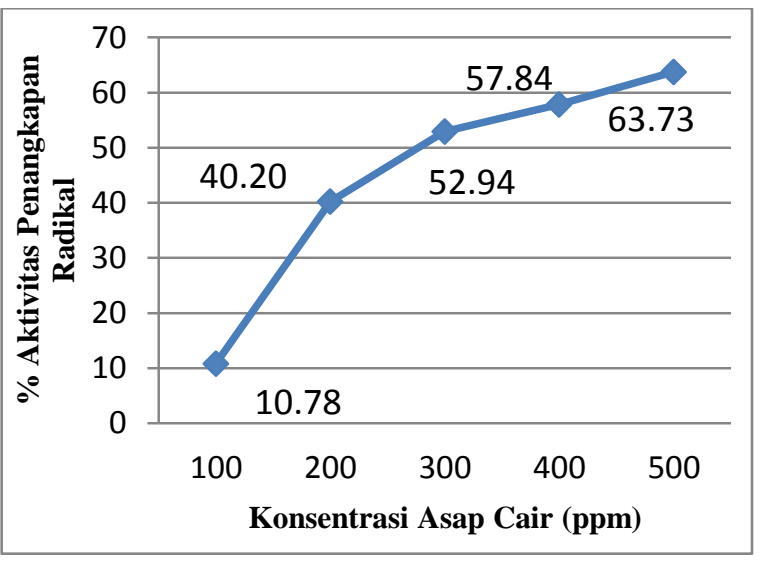

Gambar 1. Aktivitas Antioksidan Asap Cair Kayu Putih

Aktivitas penangkapan radikal bebas dari asap cair kayu putih meningkat dari $10,78 \%$ pada konsentrasi 100 ppm menjadi $63,73 \%$ pada konsentrasi 500 ppm. Menurut Pszczola (1995) dalam Apituley \& Darmadji (2013), komponen yang terdapat dalam asap cair yang berfungsi sebagai antioksidan adalah senyawa-senyawa fenol. Dimana fenol dengan titik didih yang lebih tinggi mempunyai sifat antioksidan yang lebih baik jika dibandingkan dengan senyawa fenol dengan titik didih rendah. Sedangkan Apituley dkk., (2006a ; 2006b) dalam penelitiannya tentang antioksidan fenolik asap cair cangkang sawit juga menunjukkan aktivitas penangkapan radikal bebas asap cair cangkang sawit dan redestilatnya berkisar antara $48-55 \%$ pada konsentrasi 200 ppm dengan daya reduksi yang berada pada kisaran antara $0.12-0.17$ pada konsentrasi $200 \mathrm{ppm}$. Hal tersebut hampir sama dengan hasil pengujian aktivitas penangkapan radikal bebas asap cair kayu putih dalam penelitian ini yang pada konsentrasi 200 ppm yakni sebesar $40.20 \%$. Dari hasil analisis regresi linier diperoleh persamaan garis $\mathrm{y}=-18,8+7,04(\mathrm{R} 2=0,859)$, sehingga diperoleh nilai $\mathrm{IC}_{50}$ sebesar 9,77 . Nilai $\mathrm{IC}_{50}$ adalah bilangan yang menunjukkan konsentrasi asap cair yang mampu menghambat proses oksidasi sebesar 50\%. Semakin kecil nilai $\mathrm{IC}_{5} 0$ maka semakin tinggi aktifitas antioksidannya (Hanani dkk., 2005). Berdasarkan nilai $\mathrm{IC}_{50}$ yang diperoleh, maka asap cair kayu putih memiliki aktifitas antioksidan yang baik. 


\section{Aplikasi Asap Cair Pada Ikan Tuna Asap \\ Thiobarbituric Acid (TBA)}

Hasil analisis menunjukkan bahwa nilai TBA ikan Tuna asap tanpa asap cair (kontrol/A0) dengan yang diberi perlakuan konsentrasi asap cair 2,5\% (A1) dan 5\% (A2) mengalami peningkatan selama penyimpanan. Perlakuan tanpa asap cair (A0) mengalami peningkatan nilai TBA dari 1,04 MegMDA/kg pada hari ke-0 menjadi 6,0 MegMDA/kg pada penyimpanan hari ke-10. Perlakuan asap cair $2,5 \%$ (A1) mengalami peningkatan dari $1,19 \mathrm{MegMDA} / \mathrm{kg}$ pada hari ke-0 menjadi 4,08 MegMDA/kg pada penyimpanan hari ke-10. Sedangkan perlakuan konsentrasi asap cair 5\% (A1) mengalami peningkatan dari 1,31 MegMDA/kg pada hari ke-0 menjadi 3,48 MegMDA/kg pada penyimpanan hari ke-10. Meningkatnya nilai TBA menunjukkan bahwa selama waktu penyimpanan telah terjadi degradasi atau kerusakan lemak pada jaringan daging ikan yang dapat menghasilkan malonaldehida (MDA). Salah satu faktor terjadinya pembentukan malonaldehida adalah banyaknya lemak jenuh pada jaringan daging ikan. Besar kecilnya nilai TBA sangat ditentukan oleh banyaknya malonaldehida yang terbentuk (Apituley, 2010). Hal ini diperkuat dengan pendapat Raharjo (2004), bahwa oksidasi lemak pada fase lanjut akan menghasilkan senyawa aldehid seperti 2-enel dan 2-dienal. Dimana senyawa aldehid ini dapat bereaksi dengan reagen TBA sehingga dapat dilakukan pengukuran terhadapnya. Hasil analisa nilai TBA dari perlakuan yang dilakukan dalam penelitian ini dapat dilihat pada Gambar 2. Dari Gambar 2 di atas juga terlihat bahwa peningkatan nilai TBA pada ikan yang tidak diberi perlakuan pengasapan (kontrol/A0) berlangsung lebih cepat bila dibandingkan dengan yang diberi perlakuan pengasapan asap cair kayu putih dengan konsentrasi 2,5\% (A1) dan 5\% (A2). Hasil tersebut di atas menunjukkan bahwa perlakuan pengasapan asap cair kayu putih mampu menekan terjadinya kerusakan oksidatif lemak ikan asap selama penyimpanan. Hasil yang serupa juga dikemukakan oleh Ernawati (2012) yang menyatakan laju oksidasi sosis yang diasap selama penyimpanan lebih rendah daripada laju oksidasi sosis tanpa pengasapan yang ditunjukkan dengan bilangan peroksida dan bilangan TBARS. Hal ini juga didukung oleh hasil penelitian yang dilakukan oleh Wesniati (1999); Wazyka (2000) dan Pamenang (2001) yang menunjukkan bahwa senyawa-senyawa fenolik dalam asap cair diantaranya guaiakol (2metoksi fenol) dan pirokatekol (1,2dihidroksibenzena) yang terbukti dapat mengurangi atau menghambat terjadinya kerusakan oksidatif pada asam linoleat. Beberapa penelitian tentang aplikasi asap cair sebagai biopreservasi alami dalam ikan asap menunjukkan bahwa komponen fenolik dalam asap cair dari limbah hasil pertanian seperti tempurung kelapa, batok biji pala serta cangkang kenari ternyata mampu menghambat terjadinya kerusakan oksidatif pada lemak ikan asap selama penyimpanan (Swastawati,2008; Apituley, 2010; Ernawati dkk.,2012).

\section{Asam Lemak Bebas}

Hasil analisis Asam lemak bebas ikan Tuna asap menunjukkan bahwa kadar asam lemak bebas baik pada perlakuan tanpa asap cair (A0), perlakuan konsentrasi asap cair 2,5\% (A1) dan konsentrasi asap cair 5\% (A2) mengalami peningkatan selama penyimpanan. Perlakuan tanpa asap cair (A0) mengalami peningkatan kadar asam lemak bebas dari $12,28 \%$ pada hari ke-0 menjadi $25,41 \%$ pada penyimpanan hari ke-10. Pada Perlakuan konsentrasi asap cair 2,5\% (A1) mengalami peningkatan dari $12,07 \%$ pada hari ke-0 meningkat menjadi $20,13 \%$ pada penyimpanan hari ke-10. Sedangkan perlakuan konsentrasi asap cair 5\% (A2) mengalami peningkatan kadar asam lemak bebas dari 11,01\% pada hari ke-0 meningkat menjadi $18,44 \%$ pada penyimpanan hari ke-10. Pada produk berlemak dengan kadar air dan kelembaban udara tertentu merupakan media yang baik bagi pertumbuhan jamur yang mengeluarkan enzim dan menguraikan trigliserida menjadi asam lemak bebas dan gliserol. Adanya senyawa fenolik yang terkandung dalam asap cair kayu putih ternyata dapat menghambat proses hidrolisis dan oksidasi sehingga mencegah kerusakan lemak yang terkandung pada ikan Tuna asap selama penyimpanan (Apituley \& Darmadji, 2013).

Menurut Ketaren dalam Apituley (1998), meningkatnya kadar FFA merupakan indikator terjadinya kerusakan lemak pada bahan pangan. Asam-asam lemak bebas tersebut dapat berasal dari terjadinya kerusakan secara hidrolisis karena adanya sejumlah air dalam lemak bahan pangan. Hal ini juga sesuai dengan pendapat Rahardjo (2004) yang mengemukakan bahwa adanya asam lemak bebas cenderung menunjukkan terjadinya ketengikan hidrolitik, namun masih dimungkinkan juga oleh oksidasi lemak yang menghasilkan asam-asam organik lainnya. Lawson dalam Nurhaeni (2003) juga mengemukakan bahwa reaksi hidrolisis lemak dipercepat oleh temperatur tinggi, tekanan udara dan jumlah air yang berlebihan. Adanya senyawa fenolik yang terkandung dalam asap cair kayu putih ternyata dapat menghambat proses hidrolisis dan oksidasi sehingga mencegah kerusakan lemak yang terkandung pada ikan Tuna asap selama penyimpanan (Apituley \& Darmadji, 2013). Hasil ainalisa asam lemak bebas ikan Tuna asap dapat dilihat pada Gambar 3. 
Tabel 2. Hasil Analisa Komponen Penyusun Asap Cair Kayu Putih

\begin{tabular}{|c|c|c|c|c|}
\hline No & Waktu Retensi & Senyawa & Berat Molekul & $\underset{(\%)}{\text { Kadar }}$ \\
\hline 1 & 5,225 & 2-furancarboxaldehyde & 96 & 11,01 \\
\hline 2 & 5,992 & 2-furran methanol & 98 & 1,74 \\
\hline 3 & 6,575 & 2-propanone,1-(acetyloxy) & 116 & 2,78 \\
\hline 4 & 8,350 & 2 -cyclopenten-1-one, 2 methyl & 96 & 1,26 \\
\hline 5 & 8,575 & Ethanone,1-(2-furanyl) & 110 & 1,63 \\
\hline 6 & 8,683 & $2(3 \mathrm{H})$-furanone, dihydro & 86 & 0,94 \\
\hline 7 & 10,092 & 5-methyl furfural & 110 & 4,84 \\
\hline 8 & 10,192 & 2-butanone,1-(acetyloxy) & 130 & 1,71 \\
\hline 9 & 10,600 & Phenol & 94 & 11,28 \\
\hline 10 & 10,875 & 3-Hexen,2-one,3-methyl & 112 & 1,77 \\
\hline 11 & 10.958 & 2-Furamethanol,tetrahydro & 102 & 7,80 \\
\hline 12 & 11,317 & 2-cyclopenten-1-one,2-hydroxy-3-methyl & 112 & 2,72 \\
\hline 13 & 11,692 & Phenol, 2-methyl & 108 & 2,82 \\
\hline 14 & 11,967 & Phenol, 4-methyl & 108 & 4,75 \\
\hline 15 & 12,133 & Phenol, 2-methoxy & 124 & 9,84 \\
\hline 16 & 12,483 & 3,5-Dimethyl Cyclopenteolone & 126 & 1,72 \\
\hline 17 & 12,950 & Phenol, 2-ethyl & 122 & 1,14 \\
\hline 18 & 13,217 & 2-methoxy-4-methylphenol & 138 & 6,83 \\
\hline 19 & 13958 & Phenol, 4-ethyl-2-methoxy & 152 & 3,61 \\
\hline 20 & 14,525 & Phenol, 3,4-dimethoxy & 154 & 7,50 \\
\hline 21 & 14,900 & Benzaldehyde,4-hydroxy-3-methoxy & 152 & 2,32 \\
\hline 22 & 15,183 & 1,2,4-Trimethoxybenzene & 168 & 4,54 \\
\hline 23 & 15,700 & Ethanone & 182 & 3,38 \\
\hline 24 & 20,333 & Stigmast-5-en-3-ol & 414 & 0,42 \\
\hline 25 & 20,925 & 1,2-Benzenedicarboxylic acid, dioctyl ester & 390 & 0,37 \\
\hline 26 & 21,492 & Acid methyl Ester & 468 & 0,24 \\
\hline 27 & 23,933 & 4-methyl phenylsulfonyl & 401 & 1,03 \\
\hline
\end{tabular}

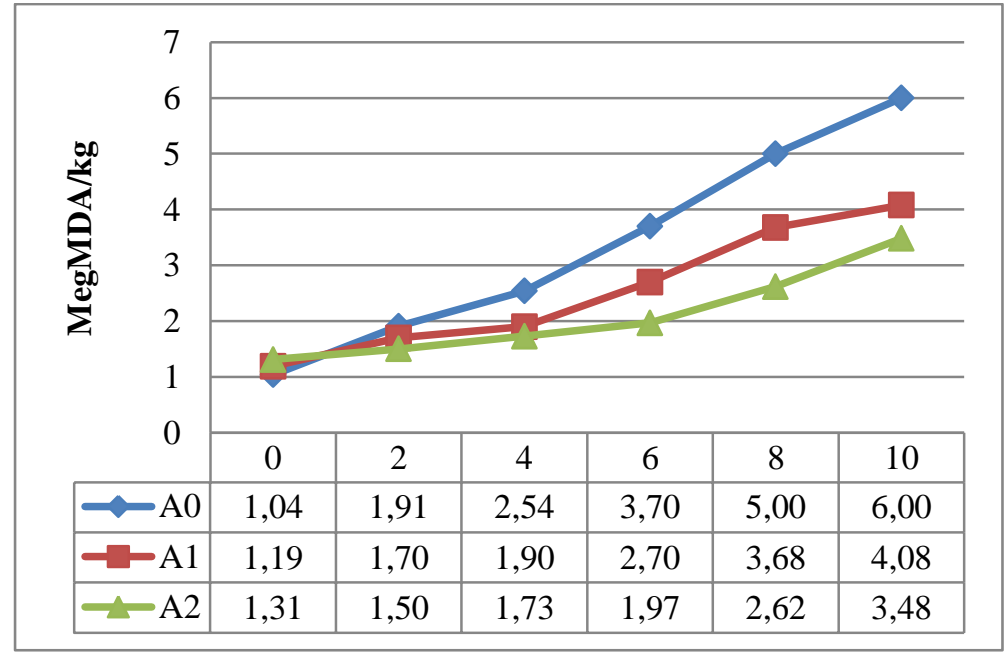

Gambar 2. Nilai TBA Ikan Tuna Asap Selama Penyimpanan 


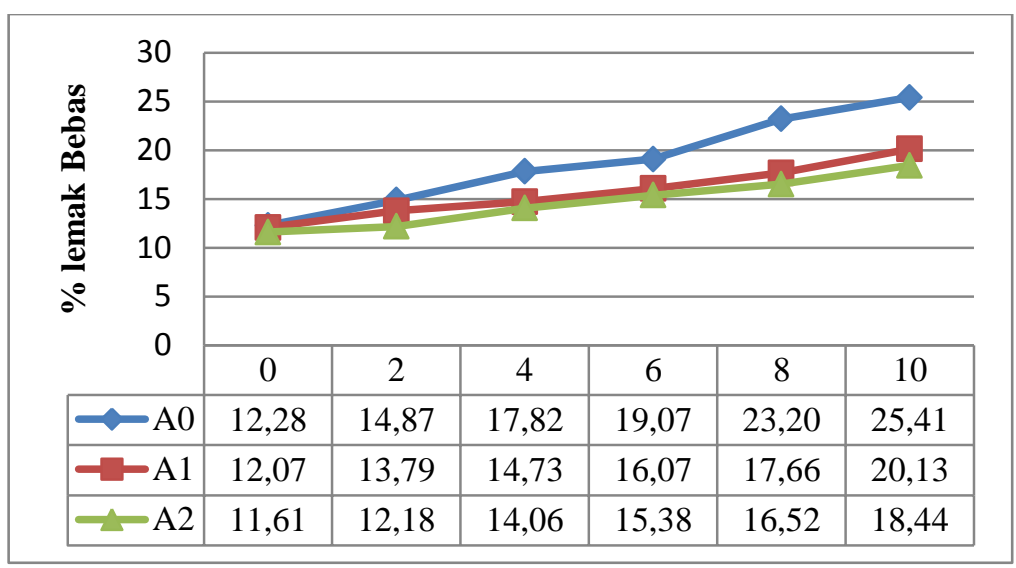

Gambar 3. Kadar Asam Lemak Bebas ikan Tuna asap

\section{KESIMPULAN}

Kesimpulan dari penelitian ini adalah asap cair dari kayu putih memiliki aktivitas sebagai antioksidan yang ditunjukkan oleh kemampuannya dalam menangkap radikal bebas DPPH. Kemampuan Asap cair kayu putih sebagai antioksidan ditunjukkan dengan perlakuan penambahan asap cair ternyata dapat menghambat laju peningkatan nilai TBA dan kadar asam lemak bebas dari ikan Tuna asap selama penyimpanan.

\section{DAFTAR PUSTAKA}

Apituley, D. A. N. 1998. Kualitas Belut Sawah (Monopterus albus) Asap Dalam "Bumbu" Selama Penyimpanan. Thesis Program Pascasarjana. Universitas Gadjah Mada. Yogyakarta.

Apituley, D.A.N., Noor, Z., Suparmo dan Darmadji,P.(2006a). Oksidasi protein daging merah dan putih dari ikan Tongkol Putih (Thunus sp) oleh sistim katalis logam $\mathrm{CuSO}_{4}-\mathrm{H}_{2} \mathrm{O}_{2}$, AGRITECH 25(4). Fakultas Teknologi Pertanian. Universitas Gadjah Mada, Yogyakarta.

Apituley, D.A.N., Noor, Z., Suparmo dan Darmadji,P.(2006b). Dampak oksidasi oleh 2,2-Azobiz (2-amidipropane) dihydrochloride (AAPH) dan sistim katalis logam $\mathrm{CuSO}_{4}-\mathrm{H}_{2} \mathrm{O}_{2}$, terhadap asam amino protein daging ikan Tongkol Putih (Thunus sp). AGRITECH 26(3). Fakultas Teknologi Pertanian Universitas Gadjah Mada, Yogyakarta.

Apituley, D.A.N. (2010). Daya Hambat Asap Cair Cangkang Kenari Terhadap Kerusakan Oksidatif Lemak Ikan Tatihu Asap. ICHTYOS 9(1):45-94). Fakultas Perikanan dan Ilmu Kelautan, Universitas Pattimura. Ambon

Apituley, D.A.N \& Darmadji P. (2013). Daya Hambat Asap Cair Kulit batang Sagu Terhadap Kerusakan Oksidatif lemak Ikan Tuna (Thunnus sp) Asap. AGRITECH 33
(2). Fakultas Teknologi Pertanian Universitas Gadjah Mada, Yogyakarta.

Burda, S \& Oleszek, W. (2001). Antioxidant and antiradical activities of flavonoids. Journal of Agriculture and Food Chemistry 49 :2774-2779.

Darmadji, P., Supriyadi \& Hidayat.(1999). Produksi asap cair limbah padat rempah dengan cara pirolisis. AGRITECH 16(4):11-15, Yogjakarta.

Ernawati.. Purnomo, H dan Estiasih,T.(2012). Efek antioksidan asap cair terhadap stabilitas oksidatif sosis ikan lele dumbo (Clarias gariepinus) selama penyimpanan. Jurnal Teknologi Pertanian 13(2): 119-124.

Girrard, J. P.(1992). Smoking in Technology Of Meat Production. Ellis Harwood Limited, New York.

Guillen,M.D \& Ibargoitia,L.(1999). Influence of the moisture conten on the composition of the liquid smoke produced in the pyrolisis of Fagus silvatica L.wood. Journal of Agriculture and Food Chemistry. 47: 4126 4136.

Halim,M. (2005). Fraksinasi, analisa kimia dan pengujian biopreservatif asap cair cangkang sawit terhadap pertumbuhan bakteri. Thesis. Program Studi Teknologi Hasil Perkebunan. Universitas Gadjah Mada. Yogyakarta.

Hanani. E.A, Munim. R \& Sekarini. (2005). Identifikasi Senyawa Antioksidan Dalam Spons Calipongia sp. Dari Kepulauan Seribu. Majalah Ilmu Kefarmasian. 11(3):127-133.

Leha, M. (2009). Pemanfaatan Cangkang Kenari sebagai Biopreservatif dalam Pengolahan Ikan Cakalang Asap. Thesis. Program Pascasarjana Program Studi Ilmu Kelautan. Universitas Pattimura. Ambon.

Maga, J.A. (1987). Smoke In Food Processing, Crc Press, Inc Boca Raton, Florida.

Nenadis, N. \& Tsimidou, M. (2002). Observations On The Estimation Of Scavenging 
Activity Of Phenolic Compounds Using Rapid 1,1-Diphenyl-2-Picrylhydrazyl (DPPH) Test. Journal American Oil Chemistry Society 79: 1191-1195.

Nurhaeni, A. 2003. Sifat Kimia Minyak Kelapa pada Berbagai Konsentrasi Ekstrak Tempe dan Waktu Penyimpanan. J, Agroland

Pamenang,S.(2001). Identifikasi, kuantifikasi dan konfirmasi senyawa aktif asap cair kayu karet yang mempunyai aktivitas antioksidan terhadap asam linoleat. Himpunan Makalah Seminar Nasional Teknologi Pangan, Semarang 9 - 10 Oktober 2001.

Raharjo,S., Sofos,J.N \& Schmidt,G.R.(1992). Optimalization of sample weight, sample blank and recovery procedures in a Thiobarbituric Acid-C18 (TBA C-18). Method for measuring TBA number in ground beef. Proceedings Western Section, American Society of Animal Science. Colorado State Uneversity Fort Collins. 43 : $317-320$.

Raharjo,S.(2004). Kerusakan oksidatif Pada Makanan. Pusat Studi Pangan dan Gizi, UGM. Yogyakarta.

Swastawati,F.(2008). Quality and safety of smoked catfish (Aries talassinus) using paddy chaff and coconut shell liquid smoke. Journal of Coastal Development.12(1): 47- 55

Tranggono, Suhardi, Bambang Setiadji, Purnama Darmadji, Supranto \& Sudarmanto. (1996). Identifikasi Asap Cair Dari Berbagai Jenis Kayu Dan Tempurung Kelapa, Jurnal Ilmu Dan Teknologi Pangan 1 (2): 15 - 24.

Wazyka,A., Darmadji,P. dan Raharjo,S. (2000). Aktivitas antioksidan asap cair kayu karet dan redestilatnya terhadap asam linoleat. Prosiding Seminar Nasional Industri Pangan 2000.

Wesniati, N., Darmadji,P dan Tranggono.(1999). Aktivitas penghambatan oksidasi lemak fraksi-fraksi asap cair tempurung kelapa (Cocos nucifera, L.) Prosiding Seminar Nasional Pangan Yogyakarta, 14 September, 1999.

Wikipedia. (2009). Kayu Putih. http://id.wikipedia.org/wiki/Kayu putih. [06/01/2012]. 